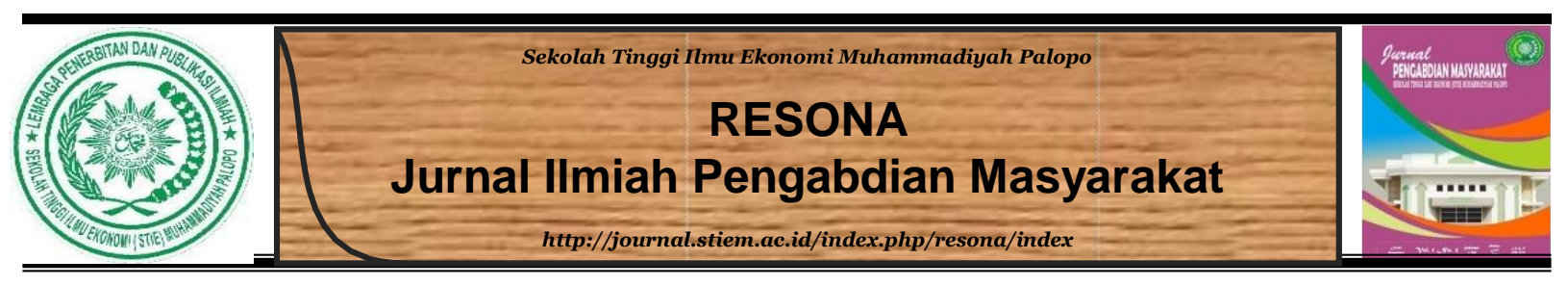

\title{
Pelatihan Penggunaan Bahasa Indonesia Dalam Media Sosial Untuk Promosi Sekolah Di Lingkungan Yayasan Al-Qomariyah Kabupaten Garut
}

\author{
${ }^{1}$ Deni Hadiansah, ${ }^{2}$ Desty Rara Pringgiandi, ${ }^{3}$ Fajar Setyaning Dwi Putra
}

${ }^{1,2,3}$ Universitas Bandung Raya

\begin{tabular}{l} 
INFO NASKAH \\
\hline Diserahkan \\
10 maret 2019 \\
Diterima \\
23 mei 2019 \\
Diterima dan Disetujui \\
28 Juni 2019 \\
\hline
\end{tabular}

\section{Kata Kunci:}

media sosial, penggunaan bahasa, promosi sekolah

\begin{abstract}
ABSTRAK
Sampai Januari 2019 pengguna media sosial di Indonesia mencapai 150 juta atau sebesar $56 \%$ dari total populasi. Angka penetrasi tersebut, menandakan luasnya penggunaan media sosial di tengah masyarakat. Media sosial terbukti ampuh mendukung promosi sekolah, hanya saja beberapa tenaga pendidik belum dapat efektif menggunakan media sosial, khususnya keterampilan penggunaan bahasa. Oleh karena itu, perlu dilaksanakan pelatihan penggunaan bahasa Indonesia untuk media promosi sekolah di lingkungan Yayasan Al-Qomariyah Kabupaten Garut. Kegiatan pelatihan ini menngunakan pendekatan persuasif edukatif melalui metode ceramah, diskusi, dan praktek. Hasil dari pelatihan dapat disimpulkan bahwa secara umum seluruh peserta memberikan respon positif, memiliki kompetensi penguasaan materi yang baik, interaktif, dan terlihat menyenangkan. Kendala yang ditemukan beberapa peserta tidak memiliki gawai yang standar dan ketersediaan jaringan internet yang kuat. Demikian perlu dilaksanakan kegiatan pelatihan secara berkala dan berkelanjutan.
\end{abstract}




\section{Pendahuluan}

Sosial media saat ini telah menjadi bagian gaya hidup (lifestyle). Dalam terminologi Kaplan dan Haenlein (2010: 59-68), media sosial adalah sebuah kelompok aplikasi berbasis internet yang membangun di atas dasar ideologi dan teknologi Web 2.0, dan memungkinkan penciptaan dan pertukaran "user-generated content". Oleh karena itu, media sosial bertautan dengan perkembangan internet. Berdasarkan hasil riset Wearesosial Hootsuite yang dirilis Januari 2019, pengguna media sosial di Indonesia mencapai 150 juta atau sebesar $56 \%$ dari total populasi. Jumlah tersebut naik $20 \%$ dari survei sebelumnya. Sementara pengguna media sosial mobile (gadget) mencapai 130 juta atau sekitar $48 \%$ dari populasi (http://databoks.katadata.co.id).

Besarnya populasi pengguna media sosial di Indonesia, tentu saja merupakan potensi bagi ekonomi digital nasional. Kemunculan e-commerce, transportasi online, toko online dan bisnis lainnya berbasis internet bukti terhadap hal tersebut. Hanya saja, masyarakat pun menggunakan media social hanya untuk berbagai tentang keseharian, mengkritisiki kebijakan pemerintah, keluah-kesah kehidupan, dan banyak pula yang menyebarkan berita bohong (hoaks). Hal ini tentu saja memiliki efek buruk pagi netizen.

Angka penetrasi media sosial bergerak tidak terbendung. Menandakan semakin tingginya populasi pengguna media sosial. Pada gilirannya, selain dipakai untuk tukar pengalaman dan penyampaian perasaan, media sosial pun telah berhasil menjadi media bisnis dan promosi yang ampuh. Hal itu dimungkinkan, sebab sifat dasar media sosial memungkinkan semua orang berkreasi dan menyebarkan konten sendiri (user-generated content), sehingga pihak manapun sepanjang memiliki akun dan terkoneksi internet dapat aktif menjadi produser konten di berbagai platform jejaring sosial.

Kaitannya media sosial sebagai media promosi, maka terdapat beberapa strategi ditinjau baik dari segi bisnis digital maupun dari penggunaan bahasa. Ihwal hal kedua, maka perlu keterampilan dalam menggunakan bahasa dalam media sosial, agar netizen tertarik dengan konten yang dipromosikan. Menurut Azwardi (2019), dewasa ini aktivitas penyampaian pesan melalui media sosial bergerak begitu deras, hampir tak dapat dibendung. Sugesti what do you think (apa yang kamu dipikirkan) telah menginspirasi dan memotivasi para netizen (warganet) untuk memainkan tombol-tombol keyboard gawainya, merangkai huruf-huruf menjadi kata, frasa, klausa, kalimat, paragraf, dan wacana. Ironisnya, semangat berkata-kata secara tertulis ini tidak dibarengi dengan sikap positif penggunaan bahasa. 
Penggunaan bahasa yang kurang tepat berpromosi dalam media sosial, acap kali mengakibatkan ketidaksesuaian komunikasi (miscommunication) antara penyampai pesan promosi dengan pembaca.Tak jarang bisa mengakibatkan kebablasan berkomunikasi (lost communication), bahkan terproduksinya berita bohong atau salah (hoaks).Keradaaan tersebut tentu saja merusak sendi-sendi komunikasi promosi yang dilakukan. Salah satu kegiatan yang dapat dilakukan dalam media sosial adalah mempromosikan sekolah. Kegiatan ini biasanya untuk menginformasikan program-program sekolah ataupun promosi untuk menjaring siswa baru. Terhadap peluang sekaligus fenomena tersebut, telah dimanfaatkan oleh Yayasan Al-Qomariyah, Kabupaten Garut. Yayasan ini berdiri sejak tahun 1991, mengelola PAUD, SD, MTs., dan SMA. Setiap tahun, sekolah-sekolah di bawah pengelolaan Yayasan Al-Qomariyah menerima peserta didik baru. Hanya saja, kendala yang dihadapi adalah bersaing dengan sekolah-sekolah negeri maupun swasta yang berada di wilayah yang sama.

Berdasarkan masalah tersebut, maka pihak Yayasan Al-Qomariyah menyusun program promosi untuk kegiatan Penerimaan Peserta Didik Baru (PPDB) setiap tahunnya. Seiring dengan kehadiran media sosial di internet, pihak yayasan pun berinisiatif mempromosikan skeolahsekolahnya melalui media sosial, baik di facebook, instagram, twitter, maupun website. Hanya saja, promosi melalui media sosial dirasa belum maksimal, sebab masih terkendala dengan keterampilan penggunaan bahasa. Oleh karena itu, maka pihak Yayasan Al-Qomariyah mengundang narasumber dari FKIP Universitas Bandung Raya untuk mengisi pelatihan penggunaan bahasa dalam media sosial untuk promosi sekolah di Yayasan Al-Qomariah. Pelatihan dimaksud, berlangsung selama 1 (satu) hari diikuti oleh para pengurus yayasan, tenaga pendidik dan kependidikan di lingkungan Yayasan Al-Qomariyah. Adapun narasumber yang diundang sebanyak 3 orang dosen sesuai dengan bidang keahlian masing-masing. Kegiatan pelatihan tersebut dianggap bagian dari pengabdian masyarakat.

\section{Masalah}

Kehadiran media sosial membawa dampak positif dan negatif. Salah satu dampak positif media sosial adalah dapat dijadikan media promosi bisnis digital ataupun kegiatan penyampaian informasi. Hanya saja, timbul beberapa masalah berkaitan dengan penggunaan bahasa Indonesia dalam media sosial, khususnya berkaitan dengan kegiatan promosi sekolah. Berkaitan dengan masalah di atas, maka perlu dilaksanakan pelatihan penggunaan bahasa Indonesia dalam media sosial untuk kegiatan promosi sekolah. Tujuannya agar kegiatan promosi sekolah bisa berjalan efektif, murah, dijangkau semua kalangan dan dapat memanfaatkan kehadiran media sosial atau 
internet di tengah masyarakat setakat ini. Tujuan lain adalah mensosialisasikan pemakaian bahasa Indonesia yang santun sekaligus menghindari penyampaian berita bohong atau palsu (hoaks) oleh masyarakat.

\section{Metode Pelaksanaan}

Kegiatan PKM ini menggunakan pendekatan persuasif edukatif untuk dengan metode ceramah, diskusi, dan praktek. Tujuannyauntuk meningkatkan softskill dan hardskillstakeholders Yayasan Al-Qomariyah Kabupaten Garut.Pendekatan ini diharapkan tersampaikannya pesanpesan bernilai edukatif yang bertujuanuntukmengubahataumemengaruhikepercayaan, sikap, danperilakuseseorangsehinggabertindaksesuaidenganapa yang diharapkanolehkomunikator. Lokasi kegiatan dilaksanakan di Yayasan Al-Qomariyah, yang berlamaat di Kampung Walahir, RT/RW 01/01, Kecamatan Sukaresmi, Kabupaten Garut. Yayasan ini berdiri sejak tahun 1991, mengelola jenjang PAUD, SD, MTs., dan SMA.Adapun waktu kegiatan dilaksanakan pada hari Senin, 17 Juni 2019, pada pukul $08.00-16.00$ WIB.

\section{Hasil dan Pembahasan}

\section{Data Peserta, Materi, dan Pemateri Pelatihan}

Pada pelaksanaan kegiatan pelatihan, dihadiri oleh peserta sebanyak 36 orang. Peserta terdiri dari tenaga pendidik PAUD, SD, MTs., dan SMA di lingkungan Yayasan Al-Qomariyah Kabupaten Garut. Adapun jumlah tenaga pendidik (guru) di lingkungan yayasan yang jumlahnya dapat dilihat pada tabel berikut.

Tabel 1. Data Jumlah Tenaga Pendidik

\begin{tabular}{c|l|l}
\hline No. & Jenjang & Jumlah \\
\hline 1 & Tenaga Pendidik PAUD & 3 orang \\
\hline 2 & Tenaga Pendidik SD & 8 orang \\
\hline 3 & Tenaga Pendidik MTs. & 31 orang \\
\hline 4 & Tenaga Pendidik SMA & 31 orang \\
\hline \multicolumn{2}{|c|}{ Jumlah Tenaga Pendidik } & 73 orang \\
\hline
\end{tabular}

Seluruh tenaga pendidik tersebut tidak semua diikutsertakan dalam kegiatan pelatihan. Pihak Yayasan Al-Qomariyah memilih guru-guru yang berusia muda, dengan asumsi lancar menggunakan media sosial. Berdasarkan kesepakatan, dipilih sebanyak 36 tenaga pendidik yang 
diikutsertakan dalam kegiatan pelatihan.

Keseluruhan kegiatan berdurasi selama 1 (satu) hari dengan beberapa tahapan kegiatan seperti pada tabel berikut.

Tabel 2. Tahapan Pelaksanaan Kegiatan

\begin{tabular}{c|l}
\hline Urutan & \multicolumn{1}{|c}{ Tahapan Kegiatan } \\
\hline I & Pelaksanan survey lokasi \\
\hline II & Menyusun teknis pelaksanaan \\
\hline III & Koordinasi dengan pihak yayasan \\
\hline IV & Mengundang peserta pelatihan \\
\hline V & Pelaksanaan pelatihan \\
\hline VI & Penyusunan laporan \\
\hline
\end{tabular}

Pada pelaksanaannya, kegiatan pelatihan dibagi ke dalam tiga sesi dengan materi sebagaimana diurutkan pada tebel berikut.

Tabel 3. Urutan Sesi dan Materi

\begin{tabular}{l|l|l}
\hline \multicolumn{1}{c|}{ Urutan } & \multicolumn{1}{|c}{ Materi } & \multicolumn{1}{c}{ Pemateri } \\
\hline Sesi & $\bullet$ Strategi promosi sekolah & Deni Hadiansah \\
Pertama & $\bullet$ Kesantunan berbahasa \\
& $\bullet$ Etika media sosial & \\
\hline Sesi & Diskusi & Desty Rara Pringgiandini \\
Kedua & & \\
\hline Sesi & Praktik pengunaan bahasa dalam & Fajar Setyaning Dwi Putra \\
Ketiga & media sosial & \\
\hline
\end{tabular}

\section{Pelaksanaan Kegiatan Pelatihan}

\section{Pelatihan Sesi Pertama}

Pada sesi pertama, peserta diberikan materi tentang media sosial, pemanfaatan media sosial, bahaya hoaks, strategi promosi, kesantunan berbahasa, dan penggunaan bahasa dalam media sosial untuk promosi sekolah. Pada sesi pertama ini dihadiri 36 peserta. 
Pada kegiatan pelatihan sesi pertama, penajaman pada materi strategi promosi melalui media sosial dan penggunaan bahasa dalam media sosial. Pada materi strategi promosi disampaikan teori menurut Anitasari (2016) yang mengemukakan 5 strategi pemasaran melalui media sosial, yaitu (1) membangun sebuah fans club, (2) bereaksi secara efektif, (3) mendengarkan yang disampaikan konsumen, (4) mengkomunikasikan pesan promosi, dan (5) menjalin relasi.

Adapun penajaman pada materi penggunaan bahasa, disampaikan ihwal sikap bahasayang berhubungan dengan tiga hal, yaitu (1) sikap yang berkaitan dengan kesetiaan terhadap bahasa (language loyality), (2) sikap yang berkaitan dengan kebanggaan terhadap penggunaan bahasa (language pride), dan (3) sikap yang berkaitan dengan kesadaran penggunaan bahasa (awareness of the norm). Ketiga sikap tersebut tecermin dari penggunaan bahasa oleh pemiliknya, baik secara lisan maupun tulisan. Pengguna bahasa yang bersikap positif senantiasa menunjukkan indikasi kesetiaan, kebanggaan, dan kesadaran dalam tulisannya.

\section{Pelatihan Sesi Kedua}

Pada sesi kedua, peserta dipandu untuk mendiskusikan ide, gagasan, maupun saran berkaitan dengan penggunaan bahasa dalam media sosial untuk kegiatan promosi sekolah. Pada sesi ini, peserta pun dipandu untuk menyusun kalimat promosi sekolah sesuai dengan tujuan yang ingin dicapai. Beberapa peserta dapat menyusun kalimat yang menarik dan persuasif, selebihnya adapula yang masih menggunakan kalimat rancu dan tidak menarik untuk dibaca.

\section{Pelatihan Sesi Ketiga}

Pelatihan sesi ketiga diisi dengan (praktek) penggunaan media sosial untuk mempromosikan sekolah dengan menggunakan bahasa yang santun. Adapun media sosial yang digunakan peserta pada saat pelatihan dapat dilihat pada tabel berikut.

Tabel 4. Penggunaan Media Sosial dalam Pelatihan

\begin{tabular}{l|l}
\hline \multicolumn{1}{c|}{ Media Sosial } & \multicolumn{1}{c}{ Jumlah Pengguna } \\
\hline Facebook & 9 orang peserta \\
\hline Instagram & 5 orang peserta \\
\hline Twitter & 2 orang peserta \\
\hline WhatsApp & 20 orang peserta \\
\hline Jumlah & 36 orang peserta \\
\hline
\end{tabular}




\section{Tantangan dan Rekomendasi Pelatihan}

Berdasarkan tiap sesi, secara umum kegiatan berjalan lancar dan tertib. Hanya saja ada beberapa peserta yang mengeluhkan hal-hal berikut.

a. Penyusunan kalimat atau fras promosi sekolah tidak bisa mendadak, sebab berkaitan dengan konten promosi dan pemilihan kata (diksi) yang baik.

b. Kegiatan promosi melalui media sosial harus didukung infrastruktur jaringan internet yang lancar, media gawai (gadget) yang standar, dan tentu saja dilengkapi dengan quota internet yang besar.

c. Penyampaian informasi sebaiknya ditampung dulu atau dikoordinasikan oleh ketua kegiatan PPDB masing-masing jenjang sekolah, sehingga tercipta kesatuan atau keutuhan informasi.

d. Kegiatan pelatihan harus dilaksanakan secara berkala dan berkelanjutan, sebab keterampilan menggunakan bahasa dan perangkat IT perlu dilatih secara berkesinambungan.

e. Perlu dipilih tenaga pendidik atau peserta pelatihan oleh pihak yayasan yang sudah cakap dan mumpuni menggunakan IT, sehingga kegiatan promosi sekolah melalui media sosial dapat berjalan efektif dan lancar.

Testimoni ataupun saran di atas pada dasarnya merupakan tantangan yang harus dihadapi baik oleh peserta maupun pemateri. Hal ini berkaitan dengan prinsip-prinsip dasar keterampilan penggunaan bahasa dan IT. Berkaitan dengqan penggunaan bahasa, memang keterampilan menulis tidak sekadar mampu menyampaikan pesan dan pesan itu dipahami oleh pembaca. Lebih dari itu, menulis harus menggunakan bahasa yang baik, benar, logis, dan sistematis sehingga pesan yang disampaikan dapat diterima secara baik oleh pembaca. Oleh karean itu, diperlukan bahasa yang efektif, yaitu bahasa yang baik, benar, logis, dan sistematis itu. Bahasa yang baik adalah bahasa yang sesuai dengan konteks; misalnya di mana, kapan, dan kepada siapa pesan ditujukan. Bahasa yang benar adalah bahasa yang sesuai dengan kaidah atau aturan. Bahasa yang logis adalah bahasa yang bernalar, masuk akal. Bahasa yang sistematis adalah bahasa yang bersistem, beraturan, dan berstruktur.

Memang terdapat sebagian orang yang mengemukakan bahwa menulis di media sosialtidak perlu terlalu memperhatikan standar penggunaan bahasa. Alasan tersebut tidak tepat, bahkan bertentangan dengan teori literasi informasi. Dalam teori literasi informasi disebutkan bahwa penulis harus menyampaikan pesannya dengan menggunakan bahasa yang standar, yaitu bahasa yang berkaidah. Hal tersebut didasari atas pertimbangan bahwa suatu pesan akan tersampaikan secara baik kepada pembaca melalui penggunaan bahasa yang efektif, terutama 
penerapan kaidah ejaan, diksi, kalimat, dan paragraf.

Selanjutnya, berkaitan dengan keterampilan penggunaan IT, pada dasarnya perlu dilatih secara berkelanjutan. Tetapi seiring kehadiran media sosial, penggunaan ini tidak terlalu rumit karena media sosial penggunaannya sudah melekat dalam keseharian para peserta. Oleh karena itu, secara umum, peserta bisa mengikuti kegiatan pelatihan dengan lancar dan baik. Hal ini dapat dilihat pada beberapa dokumentasi foto kegiatan mendiskusikan materi promosi yang akan disampaikan melalui media sosial pada sesi kedua berikut ini.

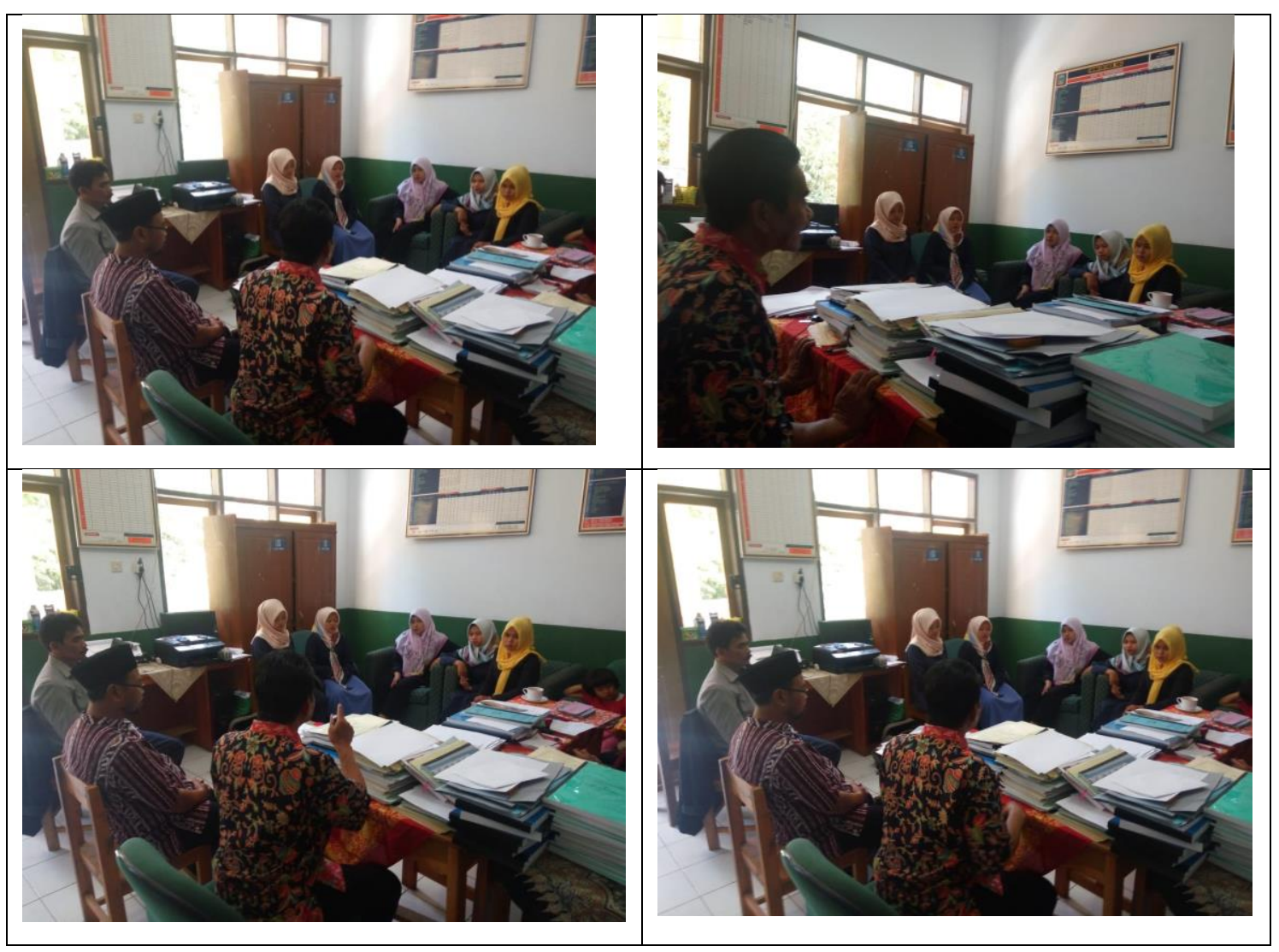

Gambar 1. Suasana Kegiatan Diskusi Pelatihan Sesi Kedua

Meskipunterdapat beberapa kendala pada saat praktik (Sesi Ketiga), namun pada saat kegiatan diskusi (Sesi Kedua), peserta nampak begitu antusias dan mengikuti diskusi secara hangat dan asyik. Oleh karena itu, pada dasarnya hampir seluruh peserta dapat mengikuti kegiatan pelatihan dengan baik. 


\section{Simpulan dan Saran}

Secara umum seluruh peserta memberikan respon positif terhadap kegiatan pelatihan. Seluruh peserta kegiatan memiliki kompetensi penguasaan materi yang baik, interaktif, menarik, dan memberi kesempatan berdiskusi. Hanya saja, beberapa peserta tidak memiliki gawai yang standar, sehingga pada saat pelaksanaan praktek kurang lancar. Hal lain, jaringan internet di tempat pelatihan relatif kurang stabil, sehingga sedikit mengganggu jalannya pelatihan.

Merujuk saran dan masukan dari para peserta, dapat disimpulkan bahwa kegiatan pelatihan diharapkan dapat dilaksanakans ecara berkala dan berkelanjutan. Oleh karena itu, peserta berharap adanya kerjasama antara pihak Yayasan Al-Qomariyah dengan FKIP Universitas Bandung Raya. Hal ini pun akan ditindaklanjuti oleh kedua belah pihak. Pada dasarnya, kegiatan pelatihan dapat berjalan dengan baik dan lancar.

\section{DAFTAR PUSTAKA}

Anitasari, Nuraini. 2016. "5 Strategi Promosi Melalui Media Sosial”, artikel dalam https:// zahiraccounting.com/, diunduh 22 Juli 2019.

Azwardi. 2019. "Kekacauan Bahasa di Media Sosial", artikel dalam https://serambinews.com, diunduh 22 Juli 2019.

Kaplan, Andreas M. dan Michael Haenlein. (2010). "Users of the world, unite! The challenges and opportunities of Social Media" dalam Business Horizons 53, (1), hlm. 59-68.

Kemristekdikti. 2018. Panduan Penelitian dan Pengabdian ke pada Masyarakat Edisi XII Tahun 2018. Jakarta: Kemristekdikti.

\section{Sumber Internet}

- https://www.garutkab.go.id/

- http://jabar.litbang.pertanian.go.id/index.php/artikel-lain/932-program-bekerja-merambahkecamatan-sukaresmi-kabupaten-garut

- http://infopublik.id/read/253847/gubernur-jabar-resmikan-jabar-caang-di-kecamatansukaresmi-garut.html

- http://databoks.katadata.co.id/ 